\title{
Case of Neuronal Intranuclear Inclusion Disease With Dynamic Perfusion Changes Lacking Typical Signs on Diffusion-Weighted Imaging
}

Mai Kikumoto, MD, Tomohisa Nezu, MD, PhD, Yuji Shiga, MD, Atsuko Motoda, MD, Megumi Toko, MD, Takashi Kurashige, MD, PhD, Hiroki Ueno, MD, PhD, Tetsuya Takahashi, MD, PhD, Hiroyuki Morino, MD, PhD, Jun Sone, MD, PhD, Yasushi Iwasaki, MD, PhD, Gen Sobue, MD, PhD, and Hirofumi Maruyama, MD, PhD

Neurol Genet 2021;7:e601. doi:10.1212/NXG.0000000000000601

Neuronal intranuclear inclusion disease (NIID) is a slowly progressive neurodegenerative disorder with a wide range of clinical manifestations, including dementia and peripheral neuropathy. ${ }^{1}$ NIID is pathologically characterized by eosinophilic hyaline intranuclear inclusions found in the central and peripheral nervous systems and various organs, including the skin, ${ }^{1,2}$ which enables the confirmation of a diagnosis by skin biopsy. ${ }^{2}$ High-intensity signals along the corticomedullary junction on diffusion-weighted imaging (DWI) and bilateral leukoencephalopathy are also specific features of NIID $^{1}$ and extend as the disease progresses. ${ }^{1,3}$ However, the clinical and pathophysiologic significance of cerebral blood flow remains undetermined. In this study, we present the case of a patient with NIID exhibiting dynamic perfusion changes on arterial spin labeling (ASL) before typical subcortical DWI signals. The patient's clinical manifestations and radiologic changes are very unique and remarkable for NIID. Her diagnosis was confirmed by skin biopsy and genomic analysis.

\section{Case Report}

A 66-year-old woman was admitted to our hospital because of recurrent transient unconsciousness and fever for 7 years. The attacks, which lasted a few days, initially occurred once a year but then increased in frequency to several attacks per year. During these attacks, the patient experienced diarrhea and vomiting. Five months after her first visit, she was transferred to our hospital because of impaired awareness, delirium, and aphasia followed by a headache. Blood and CSF examination showed no abnormalities except serum antithyroid antibodies. MRI showed hyperperfusion in the left temporal and occipital lobes on ASL. High DWI signals were observed along the left parietal and occipital cortex. Fluid-attenuated inversion recovery (FLAIR) depicted diffuse bilateral white matter hyperintensities. The hyperperfusion lesion was gadolinium enhanced on 3-dimensional T1 weighted imaging (figure, A.a-A.d). We suspected autoimmune encephalitis and administered IV steroids, which were not effective. The hyperperfusion in the left hemisphere persisted for 3 weeks. We suspected cerebrovascular abnormalities such as pial arteriovenous fistula (AVF); however, a vascular abnormality was not detected in the digital subtraction angiography. After 3 weeks, the hyperperfusion lesions shifted into the right occipital lobe; N-isopropyl-p- $\left[{ }^{123} \mathrm{I}\right]$ iodoamphetamine single-photon emission CT performed on the same day also indicated hyperperfusion in the same lesion (figure, B.a and B.d). High-intensity signals on DWI along the cortex of the left parietal and occipital lobe slightly remained, and slightly high intensity along these lesions on FLAIR indicated swelling (figure, B.b and B.c). The state of her consciousness marginally began to improve after these examinations. Although

\author{
Correspondence \\ Dr. Nezu \\ tomonezu@hiroshima-u.ac.jp
}


mitochondrial myopathy, encephalopathy, lactic acidosis, and stroke-like episodes (MELAS) was indicated by bilateral cerebral hyperperfusion, the pathologic findings and genomic analysis of her muscle biopsy specimen did not suggest any mitochondrial diseases.

Two years after the first admission, the patient was readmitted because of a high fever and unconsciousness with involuntary movements in the extremities. MRI depicted hyperperfusion in the left posterior regions on ASL, and a slightly high DWI signal was observed in the corticomedullary junction of the left frontal lobe (figure, C.a and C.b). Leukoencephalopathy had extended compared with the previous examinations (figure C.c). The slightly high DWI signal in the corticomedullary junction made us aware of the possibility of NIID; therefore, skin biopsy was performed. Immunostaining demonstrated p62-positive nuclear inclusions in the fibroblasts, sweat gland cells, and adipocytes of the skin tissue. In addition, an expansion of the GGC repeat in the 5 '-untranslated region (UTR) of the NOTCH2NLC gene was detected by repeat-primed PCR, confirming our diagnosis. Nine years after the initial attack of transient unconsciousness, we were able to diagnose this patient with NIID.

\section{Discussion}

The patient showed hyperperfusion on ASL and dynamic perfusion changes from the time of her first admission, although a specific high DWI signal appeared 2 years later. The perfusion changes were similar to those of other diseases, but radiologic follow-up contributed to the diagnosis. We diagnosed her with NIID, confirmed by skin biopsy and GGC repeat expansion in the $5^{\prime}$-UTR of NOTCH2NLC. ${ }^{4}$ This gene mutation has a broad range of phenotypes, including amyotrophic lateral sclerosis. ${ }^{5}$

Her cortical hyperperfusion lesions showed high-intensity signals on DWI, similar to the features of encephalitis and MELAS. Furthermore, the lesions appearing in the left hemisphere showed gadolinium enhancement, mimicking edematous disorders and pial AVF. ${ }^{6}$ Although patients with NIID can manifest various clinical features, ${ }^{7}$ our patient showed uncommon MR findings that made it difficult to diagnose her with NIID in the early stage. We should consider NIID as a differential diagnosis for undetermined etiology of encephalopathy syndrome in a patient with leukoencephalopathy, presenting cerebral hyperperfusion, even without

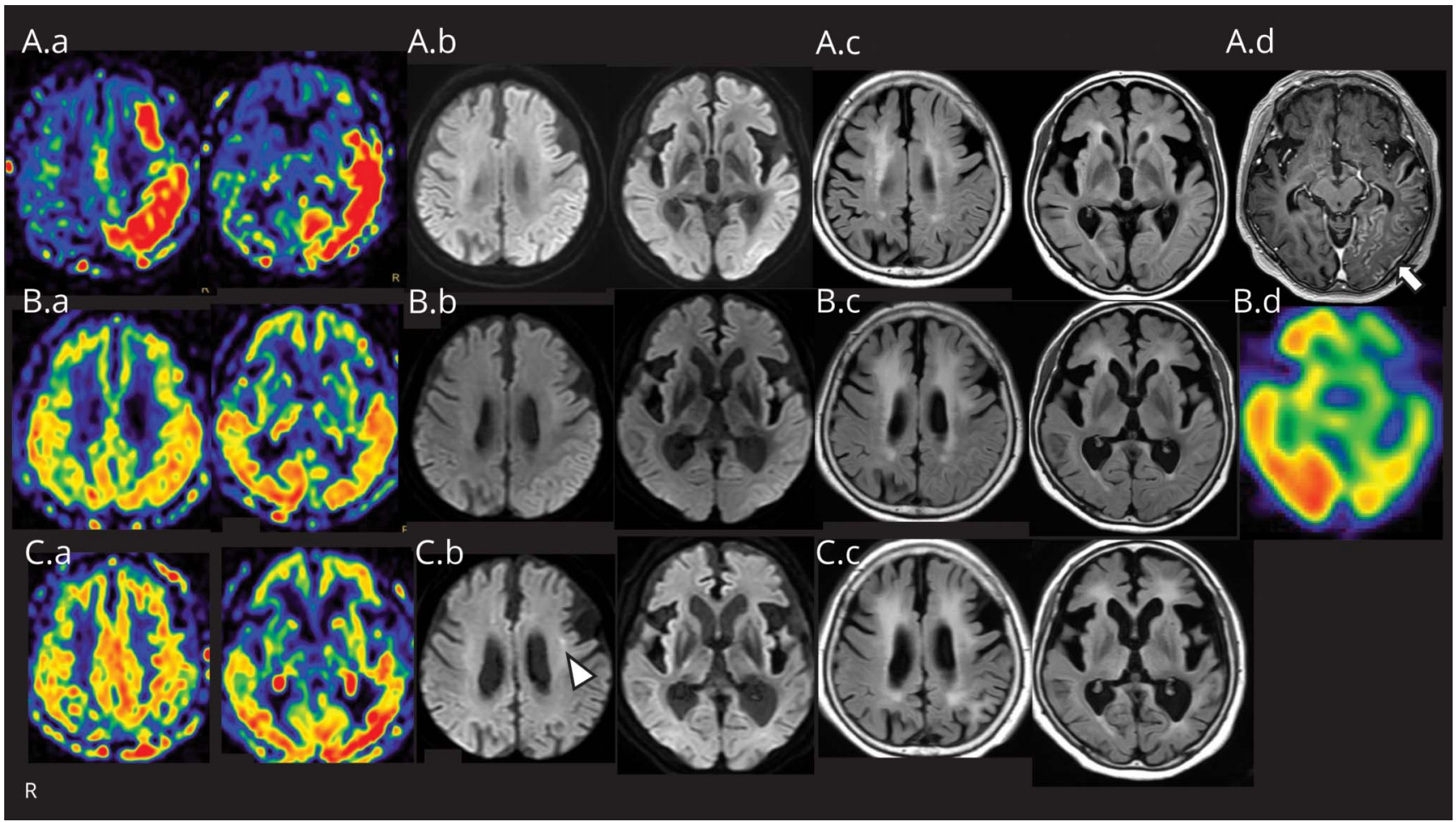

(A.a-A.d) MRI (3.0 T) scan performed at admission. (A.a) Three-dimensional pseudocontinuous ASL shows hyperperfusion in the left temporal and occipital lobe. (A.b) DWI (b value, 1,000 s/mm²) reveals high-intensity signals along the cortex in the left parietal and occipital lobe. (A.c) Bilateral WMHs are observed on FLAIR. (A.d) The hyperperfusion lesions are gadolinium enhanced on 3-dimensional T1 weighted imaging (arrow). (B.a-B.d) Studies performed 3 weeks after the day of admission. (B.a and B.d) ASL and N-isopropyl-p- $\left[{ }^{123} \mathrm{I}\right]$ iodoamphetamine single-photon emission CT performed on the same day indicate hyperperfusion in the right occipital lobe. (B.b) The high-intensity DWI signal along the left parietal and occipital cortex slightly remains. (B.c) There is slightly high intensity, which indicates swelling along the left parietal and occipital cortex on FLAIR. (C.a-C.c) MRI scan performed 2 years after the first hospitalization period. (C.a) ASL shows hyperperfusion in the left posterior regions. (C.b) A small high-intensity signal located in the corticomedullary junction of the left frontal lobe is observed on DWI (arrowhead). (C.c) WMHs expanded during recurrent major episodes. ASL = arterial spin labeling; DWI = diffusion-weighted imaging; FLAIR = fluid-attenuated inversion recovery; $\mathrm{WMH}=$ white matter hyperintensity. 
typical DWI signals in the corticomedullary junction in the early stage. Careful radiologic follow-up studies are required to distinguish NIID.

\section{Study Funding}

This study was supported by research grant from the Japan Society for the Promotion of Science KAKENHI (grant 20K16579).

\section{Disclosure}

The authors report no disclosures relevant to the manuscript. Go to Neurology.org/NG for full disclosures.

\section{Publication History}

Received by Neurology: Genetics February 11, 2021. Accepted in final form April 13, 2021.

\section{Appendix Authors}

\begin{tabular}{|c|c|c|}
\hline Name & Location & Contribution \\
\hline $\begin{array}{l}\text { Mai } \\
\text { Kikumoto, } \\
\text { MD }\end{array}$ & $\begin{array}{l}\text { Hiroshima University Hospital, } \\
\text { Hiroshima University, Japan }\end{array}$ & $\begin{array}{l}\text { Drafted and revised the } \\
\text { manuscript for } \\
\text { intellectual content }\end{array}$ \\
\hline $\begin{array}{l}\text { Tomohisa } \\
\text { Nezu, MD, } \\
\text { PhD }\end{array}$ & $\begin{array}{l}\text { Hiroshima University Hospital, } \\
\text { Hiroshima University, Japan }\end{array}$ & $\begin{array}{l}\text { Revised the manuscript } \\
\text { for intellectual content }\end{array}$ \\
\hline $\begin{array}{l}\text { Yuji Shiga, } \\
\text { MD }\end{array}$ & $\begin{array}{l}\text { Hiroshima University Hospital, } \\
\text { Hiroshima University, Japan }\end{array}$ & $\begin{array}{l}\text { Revised the manuscript } \\
\text { for intellectual content }\end{array}$ \\
\hline $\begin{array}{l}\text { Atsuko } \\
\text { Motoda, MD }\end{array}$ & $\begin{array}{l}\text { Hiroshima University Hospital, } \\
\text { Hiroshima University, Japan }\end{array}$ & $\begin{array}{l}\text { Revised the manuscript } \\
\text { for intellectual content }\end{array}$ \\
\hline $\begin{array}{l}\text { Megumi } \\
\text { Toko, MD }\end{array}$ & $\begin{array}{l}\text { Hiroshima University Hospital, } \\
\text { Hiroshima University, Japan }\end{array}$ & $\begin{array}{l}\text { Revised the manuscript } \\
\text { for intellectual content }\end{array}$ \\
\hline $\begin{array}{l}\text { Takashi } \\
\text { Kurashige, } \\
\text { MD, PhD }\end{array}$ & $\begin{array}{l}\text { National Hospital Organization } \\
\text { Kure Medical Center and } \\
\text { Chugoku Cancer Center, Japan }\end{array}$ & $\begin{array}{l}\text { Contributed to the } \\
\text { pathologic diagnosis and } \\
\text { revised the manuscript } \\
\text { for intellectual content }\end{array}$ \\
\hline
\end{tabular}

Appendix (continued)

\begin{tabular}{|c|c|c|}
\hline Name & Location & Contribution \\
\hline $\begin{array}{l}\text { Hiroki Ueno, } \\
\text { MD, PhD }\end{array}$ & $\begin{array}{l}\text { Hiroshima University Hospital, } \\
\text { Hiroshima University, Japan }\end{array}$ & $\begin{array}{l}\text { Revised the manuscript } \\
\text { for intellectual content }\end{array}$ \\
\hline $\begin{array}{l}\text { Tetsuya } \\
\text { Takahashi, } \\
\text { MD, PhD }\end{array}$ & $\begin{array}{l}\text { Hiroshima International } \\
\text { University, Higashihiroshima, } \\
\text { Japan }\end{array}$ & $\begin{array}{l}\text { Revised the manuscript } \\
\text { for intellectual content }\end{array}$ \\
\hline $\begin{array}{l}\text { Hiroyuki } \\
\text { Morino, MD, } \\
\text { PhD }\end{array}$ & $\begin{array}{l}\text { Hiroshima University Hospital, } \\
\text { Hiroshima University, Japan }\end{array}$ & $\begin{array}{l}\text { Contributed to the } \\
\text { genomic analysis and } \\
\text { revised the manuscript for } \\
\text { intellectual content }\end{array}$ \\
\hline $\begin{array}{l}\text { Jun Sone, } \\
\text { MD, PhD }\end{array}$ & $\begin{array}{l}\text { National Hospital Organization } \\
\text { Suzuka National Hospital, Japan }\end{array}$ & $\begin{array}{l}\text { Contributed to the } \\
\text { pathologic diagnosis and } \\
\text { genomic analysis and } \\
\text { revised the manuscript for } \\
\text { intellectual content }\end{array}$ \\
\hline $\begin{array}{l}\text { Yasushi } \\
\text { Iwasaki, MD, } \\
\text { PhD }\end{array}$ & $\begin{array}{l}\text { Institute for Medical Science of } \\
\text { Aging, Aichi Medical University, } \\
\text { Nagakute, Japan }\end{array}$ & $\begin{array}{l}\text { Revised the manuscript } \\
\text { for intellectual content }\end{array}$ \\
\hline $\begin{array}{l}\text { Gen Sobue, } \\
\text { MD, PhD }\end{array}$ & Nagoya University, Japan & $\begin{array}{l}\text { Revised the manuscript } \\
\text { for intellectual content }\end{array}$ \\
\hline $\begin{array}{l}\text { Hirofumi } \\
\text { Maruyama, } \\
\text { MD, PhD }\end{array}$ & $\begin{array}{l}\text { Hiroshima University Hospital, } \\
\text { Hiroshima University, Japan }\end{array}$ & $\begin{array}{l}\text { Revised the manuscript } \\
\text { for intellectual content }\end{array}$ \\
\hline
\end{tabular}

\section{References}

1. Sone J, Mori K, Inagaki T, et al. Clinicopathological features of adult-onset neuronal intranuclear inclusion disease. Brain. 2016;139(12):3170-3186.

2. Sone J, Tanaka F, Koike H, et al. Skin biopsy is useful for the antemortem diagnosis of neuronal intranuclear inclusion disease. Neurology. 2011;76(16):1372-1376.

3. Wang Y, Wang B, Wang L, et al. Diagnostic indicators for adult-onset neuronal intranuclear inclusion disease. Clin Neuropathol. 2020;39(1):7-18.

4. Sone J, Mitsuhashi S, Fujita A, et al. Long-read sequencing identifies GGC repeat expansions in NOTCH2NLC associated with neuronal intranuclear inclusion disease. Nat Genet. 2019;51(8):1215-1221.

5. Yuan Y, Liu Z, Hou X, et al. Identification of GGC repeat expansion in the NOTCH2NLC gene in amyotrophic lateral sclerosis. Neurology. 2020;95:e3394-e3405.

6. Liang H, Wang B, Li Q et al. Clinical and pathological features in adult-onset NIID patients with cortical enhancement. J Neurol. 2020;267:3187-3198.

7. Fujita K, Osaki $\mathrm{Y}$, Miyamoto R, et al. Neurologic attack and dynamic perfusion abnormality in neuronal intranuclear inclusion disease. Neurol Clin Pract. 2017;7(6): e39-e41. 


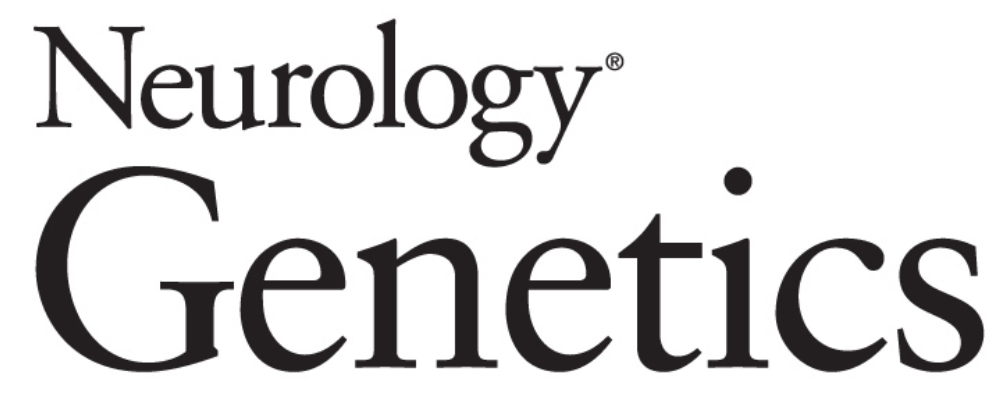

\section{Case of Neuronal Intranuclear Inclusion Disease With Dynamic Perfusion Changes Lacking Typical Signs on Diffusion-Weighted Imaging \\ Mai Kikumoto, Tomohisa Nezu, Yuji Shiga, et al. Neurol Genet 2021;7; \\ DOI 10.1212/NXG.0000000000000601}

This information is current as of June 9, 2021

Updated Information \& Services

References

Subspecialty Collections

Permissions \& Licensing

Reprints including high resolution figures, can be found at: http://ng.neurology.org/content/7/4/e601.full.html

This article cites 7 articles, 1 of which you can access for free at: http://ng.neurology.org/content/7/4/e601.full.html\#\#ref-list-1

This article, along with others on similar topics, appears in the following collection(s):

All Genetics

http://ng.neurology.org//cgi/collection/all_genetics MRI

http://ng.neurology.org//cgi/collection/mri

Information about reproducing this article in parts (figures,tables) or in its entirety can be found online at:

http://ng.neurology.org/misc/about.xhtml\#permissions

Information about ordering reprints can be found online: http://ng.neurology.org/misc/addir.xhtml\#reprintsus

Neurol Genet is an official journal of the American Academy of Neurology. Published since April 2015, it is an open-access, online-only, continuous publication journal. Copyright Copyright ( 2021 The Author(s). Published by Wolters Kluwer Health, Inc. on behalf of the American Academy of Neurology.. All rights reserved. Online ISSN: 2376-7839.

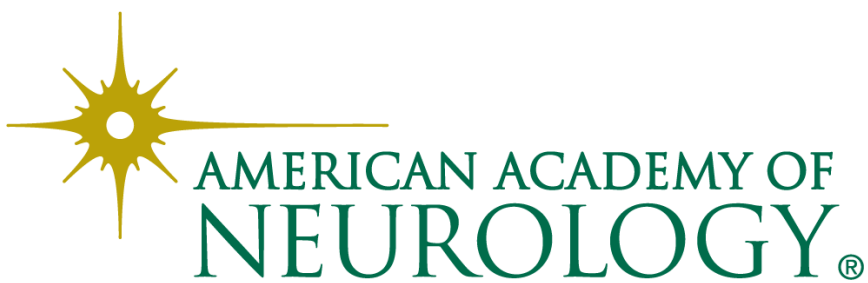

